\title{
A Computational Bible Study of What to Love and What to Hate
}

\author{
Wei Hu \\ Department of Computer Science, Houghton College, Houghton, NY, USA \\ Email: wei.hu@houghton.edu
}

Received 19 July 2014; revised 20 August 2014; accepted 12 October 2014

Copyright (C) 2014 by author and Scientific Research Publishing Inc.

This work is licensed under the Creative Commons Attribution International License (CC BY). http://creativecommons.org/licenses/by/4.0/

(c) (i) Open Access

\section{Abstract}

The Bible comprises the Old Testament of 39 books and the New Testament of 27 books. It can be viewed as the book of love, in which God revealed, out of His unconditional and unchanging love, His plan for the redemption of man in the Old Testament and fulfilled His promise made in the Old Testament by offering the one and only way of salvation through His son Jesus in the New Testament. In this study, we selected the Bible verses that contain the word love or its variation, which were then employed to cluster the books of the Bible with a computational approach. Of the 28 books containing the word love in the Old Testament, seven groups were identified: Genesis, Deuteronomy, Proverbs, Psalms, Song of Songs, First Samuel, and the rest of the other books. From the 26 books containing the word love in the New Testament, five groups were recognized: First Corinthians, John, First John, Luke and Mark and Matthew, and the rest of the other books. Furthermore, the major theme of love in each cluster was also elucidated. The opposite of love is hate. To gain the whole picture of love, we also selected Bible verses that contain the word hate or its variations. From clustering the books containing hate, different contexts of the word hate were recognized, teaching us to hate those that are contrary to love. Taken together, this computational study of the Bible demonstrated that God's law is designed to love and to love fulfills the law completely and perfectly. Our findings provided a complete catalog of different contexts and themes in which the word love is being presented in the Bible, thereby enabling better understanding of the Bible in this regard.

\section{Keywords}

Bible, Love, Clustering

\section{Introduction}

The question “what is love?” was asked more than any other Google queries in 2012 according to http://www.today.com, 
reflecting the crucial significance and need of love, since a life without love is no life. In the world of today, so many strategies have been proposed to feel love, find love, or earn love as this world does desperately want more love. Love is defined in terms of action, attitude, and behavior. Our contemporary use of love usually refers to our feelings such as we love baseball or we love pizza. However, real love is purposeful rather than emotional.

People can give different definitions or meanings of love and much research has been conducted on the subject of love (Cowburn, 2003; Lamb, 1997; Soble, 1989; Chapman, 2009), but in this report we sought a computational Bible study of this important question. The Bible is composed of Old Testament (OT) and New Testament (NT). Based on contents, the 39 books in the Old Testament can be categorized into five groups, Law of Moses, history of Israel, poetry, major prophets, and minor prophets. The New Testament contains 27 books that can be divided into five sections as well, four Gospels, history of church, Pauline epistles, general epistles, and prophecy. The Old Testament is revealed in the New Testament while the New Testament is hidden in the Old Testament, with one illuminating the other.

In the Bible, God revealed Himself to man as God of creation, sovereignty, justice, holiness, faithfulness, mercy, and grace, demonstrating the highest form of love: God's love for man. As a result, the Bible could be considered as a great love book. In this study, we sought to categorize the contexts of the word love in the Bible and to identify the love theme in each of such contexts. The opposite of love is hate. To fully understand love as presented in the Bible, we also selected the Bible verses that contain the word hate or its variations. Our aim was to find out in what context this word of hate is used in the Bible.

\section{Materials and Methods}

\subsection{The Text of the Bible}

The text of the Bible used in this study is the King James version (1611 authorized version), downloaded from http:// printkjv.ifbweb.com.

\subsection{Affinity Propagation}

The affinity propagation (AP) clustering algorithm (Frey \& Dueck, 2007) aims to search exemplars from data to represent clusters through message passing. The data points within a cluster connect to the exemplar that best represents them.

\subsection{Topic Model}

Topic models explore the correlation between the observed words in documents and the latent topics in these documents, where each topic is defined by a group of related keywords (Griffiths \& Steyvers, 2004; Griffiths, Steyvers, \& Tenenbaum, 2007; Steyvers \& Griffiths, 2007). The Latent Dirichlet Allocation (LDA) (Blei, Ng, \& Jordan, 2003) is a simple topic model that assumes each document is a mixture of various topics. It uses generative probabilistic model to represent the topics in documents as probabilistic distributions, which could then be used to estimate the similarity between documents.

In the current study, the AP clustering algorithm was applied to group the books in the Old and New Testaments, in which each book was represented by its topic distribution as a vector in Euclidean space.

\section{Results}

We present our clustering analysis of the Bible verses in the Old Testament and New Testament containing the word love, hate, and love and hate, respectively. Several networks of love were created using some main characters as nodes, which were then connected with an edge if two nodes appeared in the same verse. A community detection algorithm was applied to each network and the communities found therein were displayed with different colors.

\subsection{What to Love}

\subsubsection{Clustering Books of the Old Testament by Love}

There are 11 books in the OT that do not have the word love or its variations: 1 Chronicles, Ezra, Habakkuk, 
Haggai, Joel, Jonah, 2 Kings, Lamentations, Nahum, Numbers, Obadiah. As a result, there are 28 books in the OT that do, which were clustered, by the AP clustering algorithm, into seven groups (Table 1).

Next, we exhibit the word cloud of the most frequent words (Figures 1-7), the love theme, and representative verses in each group.

\begin{tabular}{|c|c|}
\hline Cluster number & Books in one cluster \\
\hline 1 & Deuteronomy \\
\hline 2 & Genesis \\
\hline 3 & $\begin{array}{l}\text { Amos, Chronicles2, Daniel, Ecclesiastes, Esther, Exodus, Ezekiel, Hosea, Isaiah, Jeremiah, Job, Joshua, } \\
\text { Judges, Kings1, Leviticus, Malachi, Micah, Nehemiah, Ruth, Samuel2, Zechariah, Zephaniah }\end{array}$ \\
\hline 4 & Proverbs \\
\hline 5 & Psalms \\
\hline 6 & Samuel1 \\
\hline 7 & Song of Songs \\
\hline
\end{tabular}

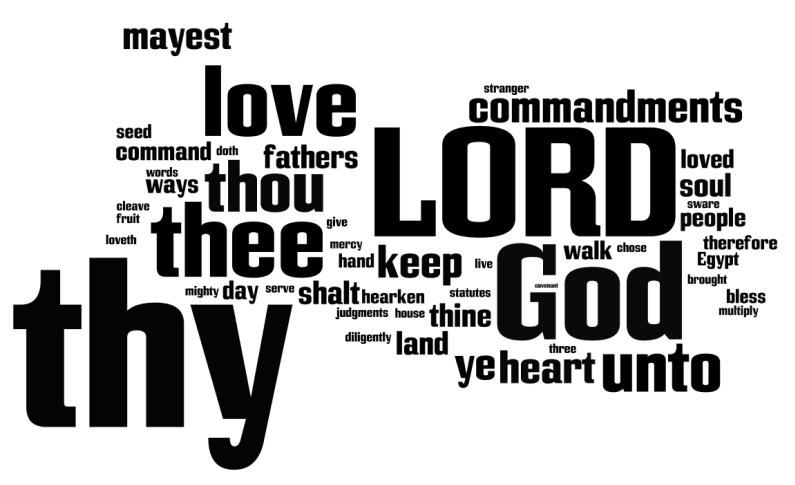

Figure 1. Most frequent words in Deuteronomy.

Theme: Love the Lord thy God by keeping His commandments.

The Ten Commandments of God are given in Deuteronomy 5:4 - 21 as well as in Exodus 20:1 - 17 .

Deuteronomy 5:10 And shewing mercy unto thousands of them that love me and keep my commandments.

Deuteronomy 6:5: And thou shalt love the Lord thy God with all thine heart, and with all thy soul, and with all thy might.

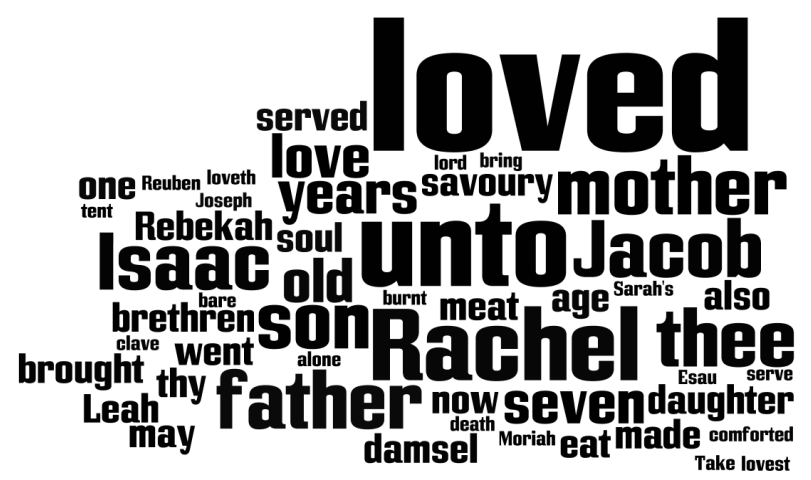

Figure 2. Most frequent words in Genesis.

Theme: Family love among father, mother, son, daughter, brother, Rachel, Isaac, Jacob, Rebekah, Leah. Genesis 25:28 And Isaac loved Esau, because he did eat of his venison: but Rebekah loved Jacob. 
Genesis 29:18 And Jacob loved Rachel; and said, I will serve thee seven years for Rachel thy younger daughter.

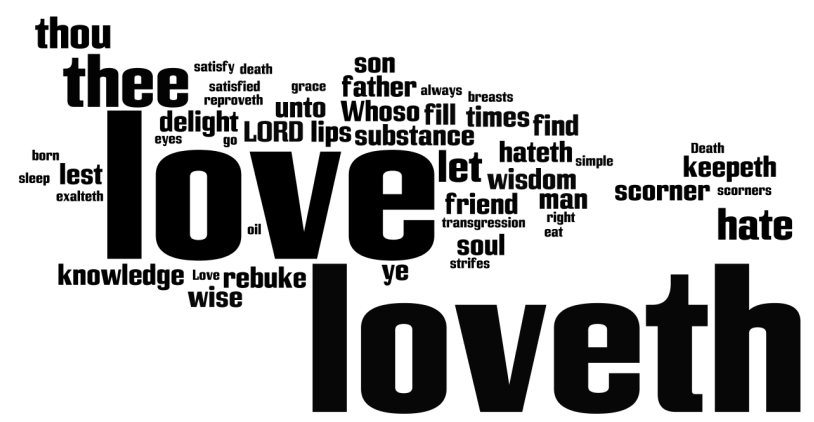

Figure 3. Most frequent words in Proverbs.

Theme: God is the source of wisdom and love. As a result, wisdom = love the Lord, knowledge, and rebuke. In another word, foolish people hate God, wisdom, knowledge, and rebuke.

We have to make many choices in life: wisdom or foolishness, light or darkness, love or hatred, heaven or hell. The choices presented in the Proverbs are matters of moral character, not intelligence. The biblical foolishness means lack of morality. Therefore, an intelligent person could be very foolish in morality. True wisdom must be based on principles and righteousness.

Proverbs 6:16 - 19 These six things doth the Lord hate: yea, seven are an abomination unto him: A proud look, a lying tongue, and hands that shed innocent blood, an heart that Deviseth wicked imaginations, feet that be swift in running to mischief, a false witness that speak eth lies, and he that sow eth discord among brethren.

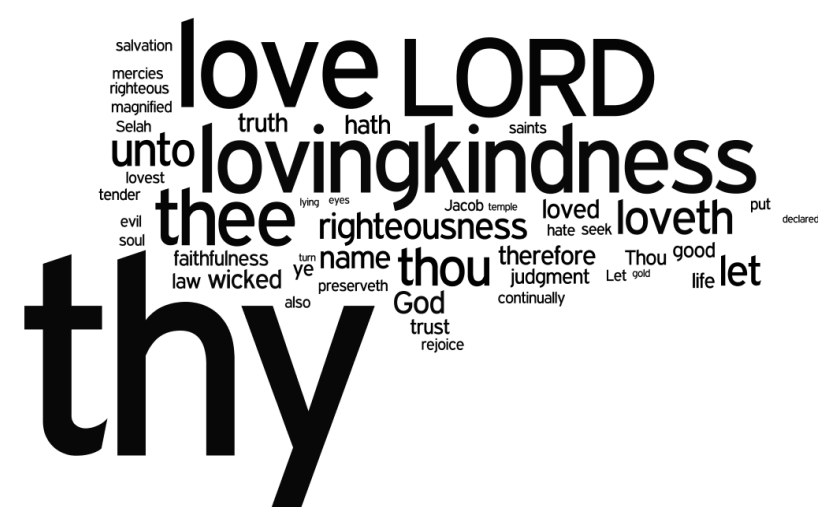

Figure 4. Most frequent words in Psalms.

Theme: Praise and love the Lord for thy loving kindness, righteousness, and truth. Psalm 18:1 I will love thee, O Lord, my strength.

Psalm 33:5 He loveth righteousness and judgment: the earth is full of the goodness of the Lord.

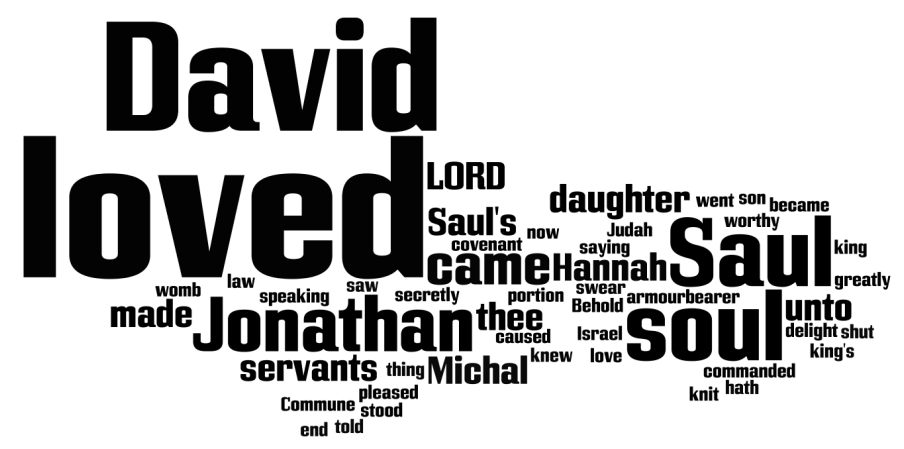

Figure 5. Most frequent words in 1 Samuel. 
Theme: Love among families and friends. Love among David, Michal (his wife and daughter of Saul), Jonathan (son of Saul), Saul (his father-in-law) and the love between Hannah and her husband.

The friendship between David and Jonathan proves that friendship based on love is true friendship, whereas friendship based on sin is not. The books of Samuel cover the period of 150 years in the history of Israel. These two books describe Samuel, the judge, prophet, and priest, Saul, the first king of Israel elected by the people, and David, the second king selected by God and the best king of this nation. The nation of Israel started from one family of Abraham, a big family of Jacob with 12 sons, and then a nation and country of 12 tribes from the 12 sons of Jacob under the kings of Saul, David, and Solomon (son of David). It is obvious to see that God is the maker of this nation, a people chosen by God.

1 Samuel 18:16 But all Israel and Judah loved David, because he went out and came in before them.

1 Samuel 18:20 And Michal Saul's daughter loved David: and they told Saul, and the thing pleased him.

1 Samuel 20:17 And Jonathan caused David to swear again, because he loved him: for he loved him as he loved his own soul.

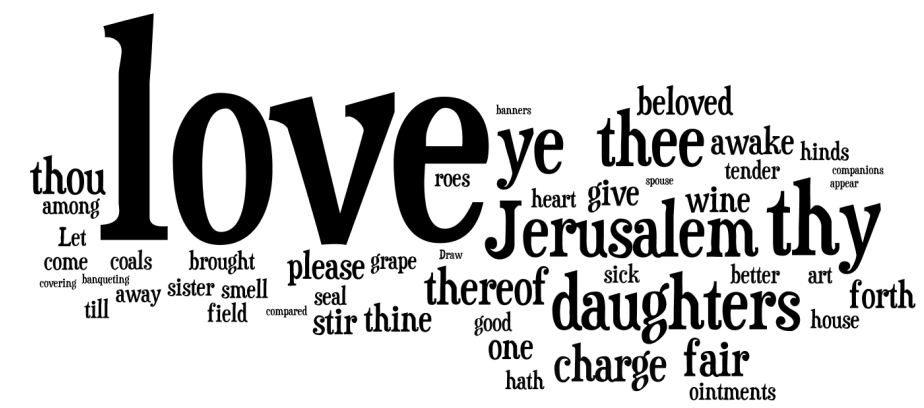

Figure 6. Most frequent words in Song of Songs.

Theme: A love letter that describes the love between two young lovers, which is similar to the love between God and mankind.

There is no mention of God in this book. Another such book is Esther. In the Bible, the love between God and the Israelites is usually described as the love between the husband (God) and the wife (Israelites).

Song of Songs 1:2 Let him kiss me with the kisses of his mouth: for thy love is better than wine.

Song of Songs 1:9 I have compared thee, O my love, to a company of horses in Pharaoh's chariots.

Song of Songs 5:8 I charge you, O daughters of Jerusalem, if ye find my beloved, that ye tell him, that I am sick of love.

Song of Songs 7:10 I am my beloved's, and his desire is toward me.

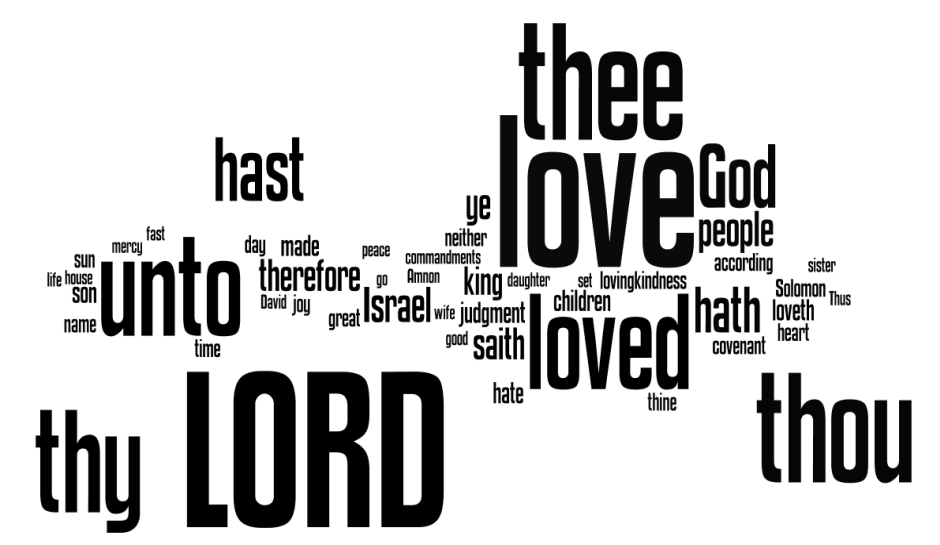

Figure 7. Most frequent words in other books.

Theme: Love the Lord thy God and love thy neighbor as thyself.

Although this love theme is repeated many times in the New Testament, but actually it is first introduced in the Old Testament. 
The text of Ten Commandments of God appears twice in the Bible: in Deuteronomy 5:4 - 21 and Exodus 20:1

- 17. Therefore, several verses in this group are the same as those in the group of Deuteronomy.

Leviticus 19:18: Thou shalt not avenge, nor bear any grudge against the children of thy people, but thou shalt love thy neighbour as thyself: I am the Lord.

Exodus 20:6 And shewing mercy unto thousands of them that love me, and keep my commandments.

Jeremiah 31:3 The Lord hath appeared of old unto me, saying, Yea, I have loved thee with an everlasting love: therefore with loving kindness have I drawn thee.

\subsubsection{Clustering Books of the New Testament by Love}

There is only one book, Acts, in the NT that does not include the word love or its variations. The 26 books in the NT that do were clustered into five groups (Table 2). Our main task then was to uncover the love theme in each of these clusters, in addition to the word cloud of top words (Figures 8-12) and the representative love verses.

Table 2. Groups of books in the New Testament by love.

Cluster number

Figure 8. Most frequent words in 1 Corinthians.

Theme: Charity = self-giving love that expects nothing in return $=$ an act of will or a decision to love without any condition.

When discussing love in the Bible, we cannot miss the famous love chapter, chapter 13 of First Corinthians, in which Paul paints different portraits of love and defines love in such a complete and beautiful way as loving God is equated with knowing and obeying His commands, for love is an action, not an emotion. Paul describes the practical side of love by showing what love does and does not do in our daily life. He emphasizes the importance of love and details the permanency of love.

Most of the modern translations of this chapter use the word love for charity in the King James Version. There are 28 instances of using the word charity in the King James, all occur in the New Testament. Nowadays, the word charity usually refers to making a donation for good causes. The word charity or love in the Bible is primarily used to define a willful commitment to sacrificial action for others, in clear contrast to the selfish love of man. The King James translators used the word charity to highlight this distinction. Among the three key elements in life, love, faith and hope, love forms the foundation for the other two. Without love, there is no faith, and without faith, there is no hope. Therefore, Paul regards love as greater than faith and hope (1 Corinthians 13:13). The love chapter of this book explains that it is possible to give without loving, but it is impossible to love without giving. The real matter of love is not about what we do, but how and why. 
1 Corinthians 13:1:4 Though I speak with the tongues of men and of angels, and have not charity, I am become sounding brass, or a tinkling cymbal. And though I have prophecy, and understand all mysteries, and all knowledge; and though I have all faith, so that I could remove mountains, and have not charity, I am nothing. And though I bestow all my goods to feed the poor, and though I give my body to be burned, and have not charity, it profiteth me nothing. Charity suffereth long, is kind; charity envieth not; charity vaunteth not itself, is not puffed up.

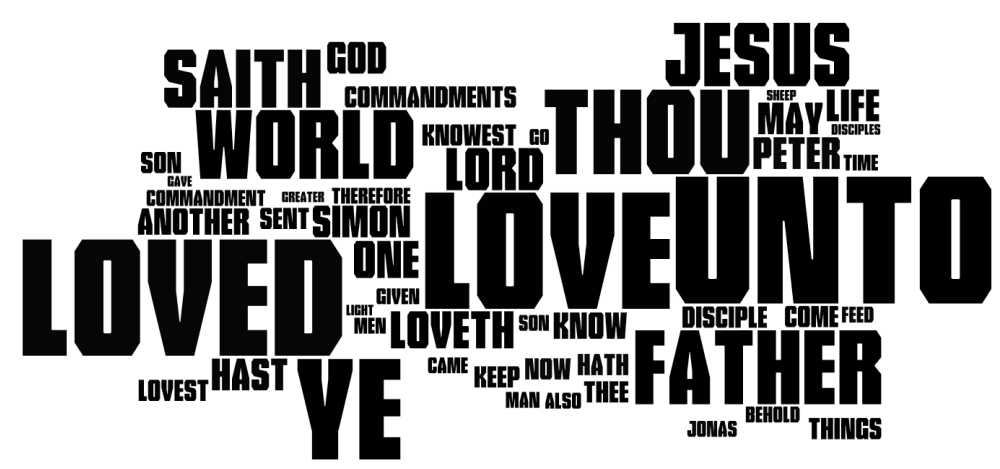

Figure 9. Most frequent words in John.

Theme: The Father (God) loves his Son (Jesus) and you, the Son and you love the Father, and you love one another.

Key words: Love, Jesus, father, world, Lord, Peter, Simon, God, life, disciple, son.

John 3:16 For God so loved the world, that he gave his only begotten son, that whosoever believeth in him should not perish, but have everlasting life.

John 14:15 If ye love me, keep my commandments.

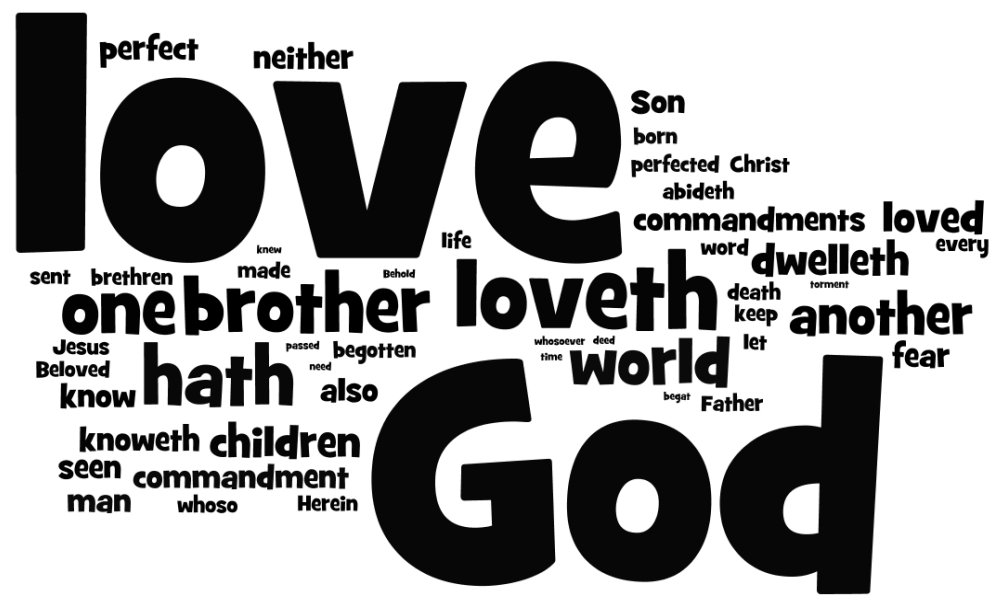

Figure 10. Most frequent words in 1 John.

Theme: Love God because He loved us first and love one another (our brothers) as children of God.

First John uses the word brother more often than the word one another. Note the Gospel of John only uses the word one another, but does not use the word brother in its love verses. Further, John tends to favor many contracts such as light and darkness, life and death, love and hate, truth and lies.

1 John 2:15 Love not the world, neither the things that are in the world. If any man love the world, the love of the Father is not in him.

1 John 4:8 He that loveth not knoweth not God; for God is love.

1 John 4:7 Beloved, let us love one another: for love is of God; and every one that loveth is born of God, and knoweth God. 


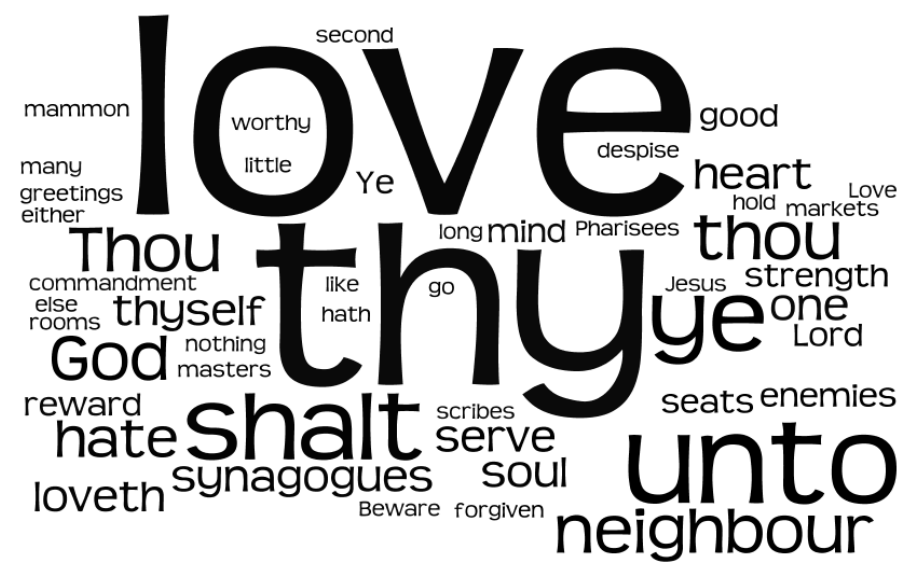

Figure 11. Most frequent words in Matthew, Mark, and Luke.

Theme: Thou shalt love the Lord thy God, thy neighbor, and thy enemies.

Our most important responsibility in life is to love God and the second is to love other people including our enemies. Sometimes, it is really difficult to love those who hate us. But the teachings of these three Gospel books underscore this kind of love, which is possible only with the change of our heart by God's love. Overall the NT calls for the change of heart by God's love as compared to the call for the change of actions by God's law in the OT, although there is a clear spiritual dimension of the law.

Luke 6:27 But I say unto you which hear, Love your enemies, do good to them which hate you.

Mark 12:30 And thou shalt love the Lord thy God with all thy heart, and with all thy soul, and with all thy mind, and with all thy strength: this is the first commandment.

Mark 12:31 And the second is like, namely this, Thou shalt love thy neighbour as thyself. There is none other commandment greater than these.

Matthew 5:43 Ye have heard that it hath been said, Thou shalt love thy neighbour, and hate thine enemy.

Matthew 5:44 But I say unto you, Love your enemies, bless them that curse you, do good to them that hate you, and pray for them which despitefully use you, and persecute you;

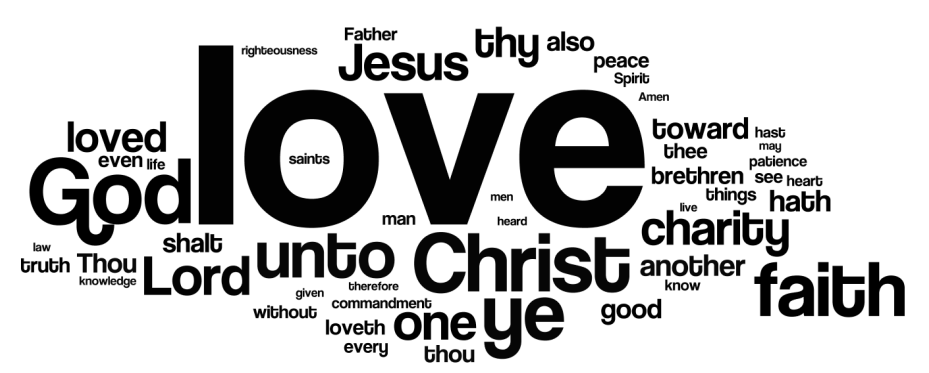

Figure 12. Most frequent words in other books.

Theme: God loves us; as a response, we must love the Lord our God, Christ Jesus, and our brothers.

(Note the word charity, the highest form of love, appeared a few times in this group.)

Romans 5:8 But God commendeth his love toward us, in that, while we were yet sinners, Christ died for us.

Romans 12: 9 Let love be without dissimulation. Abhor that which is evil; cleave to that which is good.

Ephesians 3:17 That Christ may dwell in your hearts by faith; that ye, being rooted and grounded in love.

1 Peter 4:8 And above all things have fervent charity among yourselves: for charity shall cover the multitude of sins.

\subsubsection{Love Networks of Main Characters in OT and NT}

For each of a few selected groups, we created a network of love by connecting the main figures as nodes with an edge if two nodes appeared in the same verse in one group. We then ran community detection algorithm walk trap (Pons \& Latapy, 2006) on each network and the communities found in this network were displayed with 
different colors (Figures 13-16). Our results visualized the love stories in these groups. We also included several love verses that connected the nodes in each network.

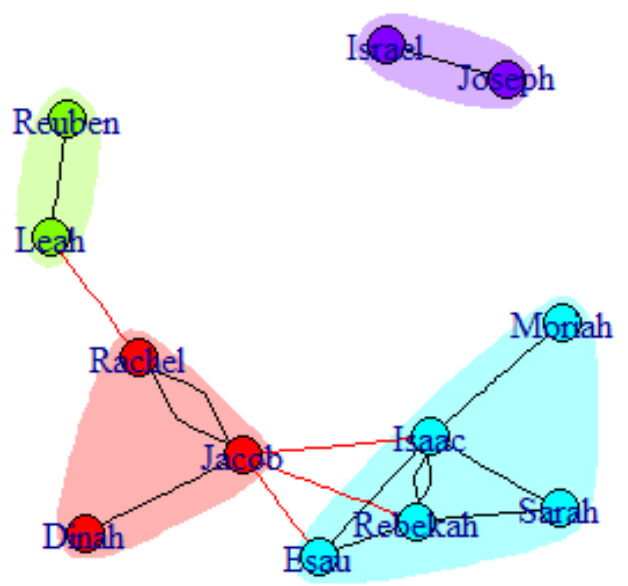

\section{Figure 13. Love network of Genesis.}

This network of love was made of the family members of Jacob. The two outlier nodes showed that Israel (Jacob) loved Joseph. The two nodes Israel and Joseph were not connected to the main core, because Jacob had another name Israel, a name given by God. Here are some love verses that were used to add an edge to two nodes in this network.

Genesis 37:3 Now Israel loved Joseph more than all his children, because he was the son of his old age: and he made him a coat of many colours.

Genesis 29:32 And Leah conceived, and bare a son, and she called his name Reuben: for she said, surely the Lord hath looked upon my affliction; now therefore my husband will love me.

Genesis 34:3 And his soul clave unto Dinah the daughter of Jacob, and he loved the damsel, and spake kindly unto the damsel. (Here the word damsel means a young unmarried woman.)

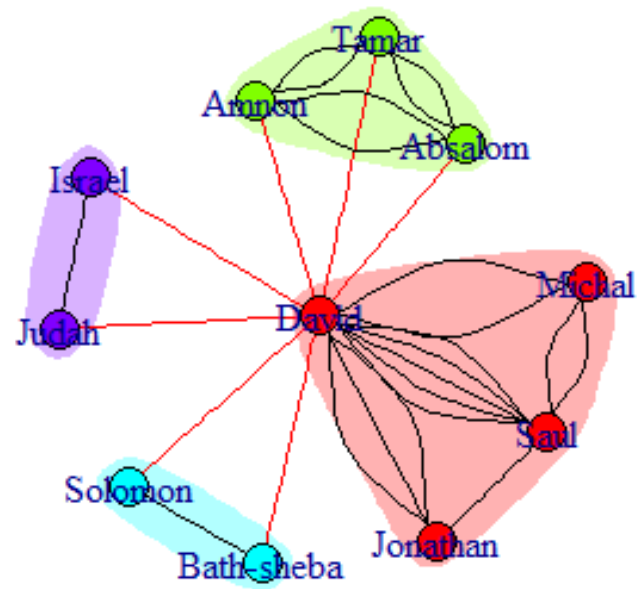

Figure 14. Love network of First and Second Samuel.

This love network mainly comprised the family members of David. Here are some love verses that were used to add an edge to two nodes in this network.

1 Samuel 18:20 And Michal Saul's daughter loved David: and they told Saul, and the thing pleased him.

1 Samuel 18:3 Then Jonathan and David made a covenant, because he loved him as his own soul.

2 Samuel 12:24 And David comforted Bath-sheba his wife, and went in unto her, and lay with her: and she bare a son, and he called his name Solomon: and the Lord loved him. 


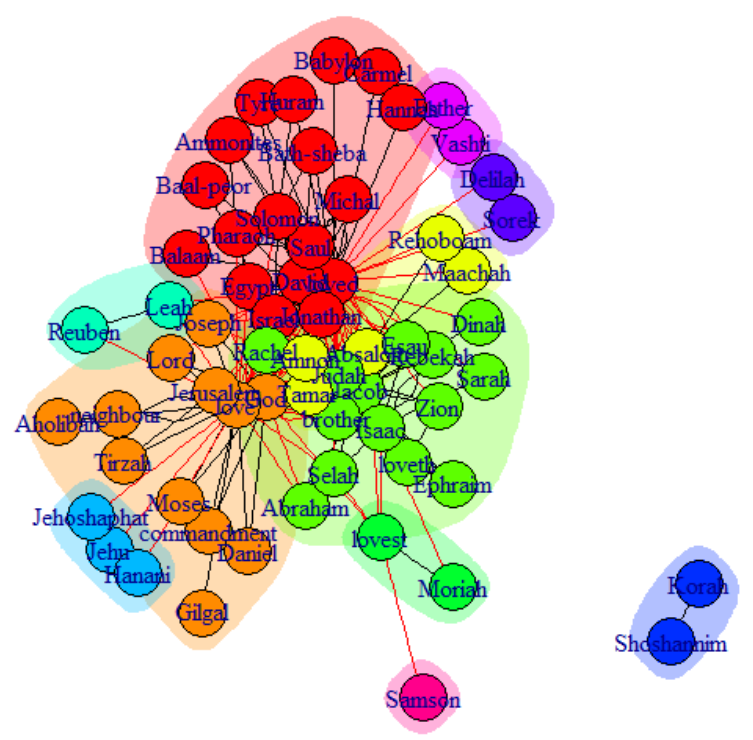

Figure 15. Love network of books in OT.

This network contained various love stories in the OT, in which Moses was grouped with commandment. We chose the verses that explained some of the outliers of this network such as Samson, Karah, and Shoshannim. A verse containing Balaam was selected as well to illustrate the context of the node Balaam.

Deuteronomy 23:5 Nevertheless the Lord thy God would not hearken unto Balaam; but the Lord thy God turned the curse into a blessing unto thee, because the Lord thy God loved thee.

Isaiah 48:14 All ye, assemble yourselves, and hear; which among them hath declared these things? The Lord hath loved him: he will do his pleasure on Babylon, and his arm shall be on the Chaldeans.

Judges 14:16 And Samson's wife wept before him, and said, Thou dost but hate me, and lovest me not: thou hast put forth a riddle unto the children of my people, and hast not told it me. And he said unto her, Behold, I have not told [it] my father nor my mother, and shall I tell it thee?

Psalms 45:1 To the chief Musician upon Shoshannim, for the sons of Korah, Maschil, A Song of loves.

Joshua 22:5 But take diligent heed to do the commandment and the law, which Moses the servant of the Lord charged you, to love the Lord your God, and to walk in all his ways, and to keep his commandments, and to cleave unto him, and to serve him with all your heart and with all your soul.

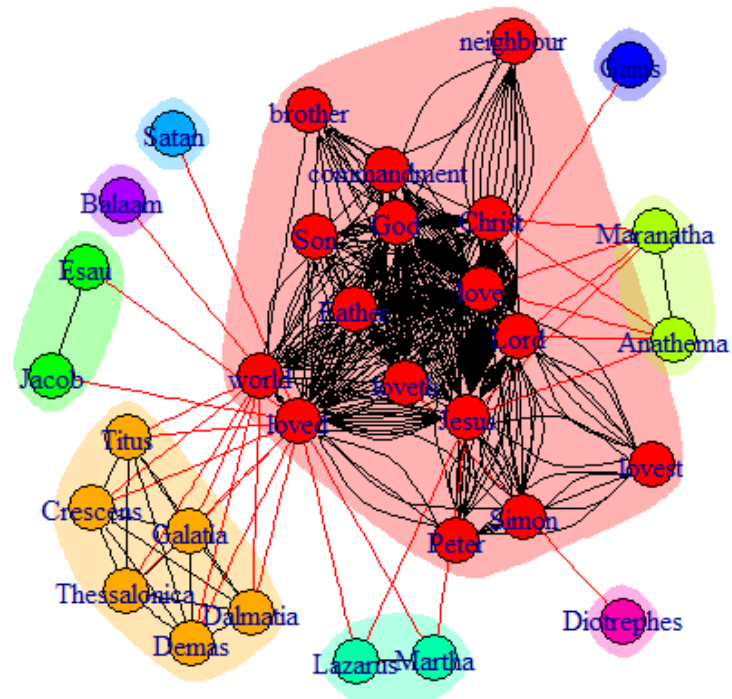

Figure 16. Love network of books in NT. 
This network visualized the love stories in the NT. One notable difference between the two love networks of the OT and NT was that the two nodes brother and neighbor were more prominent in the NT network than in the OT network, as the NT repeatedly emphasizes to love your brothers and neighbors. Here are some verses that contain the outlier nodes in this network.

3 John 1:1 The elder unto the well beloved Gaius, whom I love in the truth.

3 John 1:9 I wrote unto the church: but Diotrephes, who loveth to have the preeminence among them, receiveth us not.

2 Peter 2:15 Which have forsaken the right way, and are gone astray, following the way of Balaam the son of Bosor, who loved the wages of unrighteousness.

Revelation 3:9 Behold, I will make them of the synagogue of Satan, which say they are Jews, and are not, but do lie; behold, I will make them to come and worship before thy feet, and to know that I have loved thee.

\subsection{What to Hate}

People tend to think love is always good and hate is always bad. But should we love or hate evil? Rebuke of sin is an act of love. Sin is to transgress those boundaries or miss the target God has set for us.

\subsubsection{Clustering Books of the Old Testament by Hate}

The books in the OT that contain the word hate were grouped into seven clusters (Table 3), the same number as those grouped by love. Here books of Ezekiel and 2 Samuel formed their own clusters whereas books of 1 Samuel and Song of Songs made their own clusters by the word love. Each group is presented with a word cloud (Figures 17-23) and a hate theme.

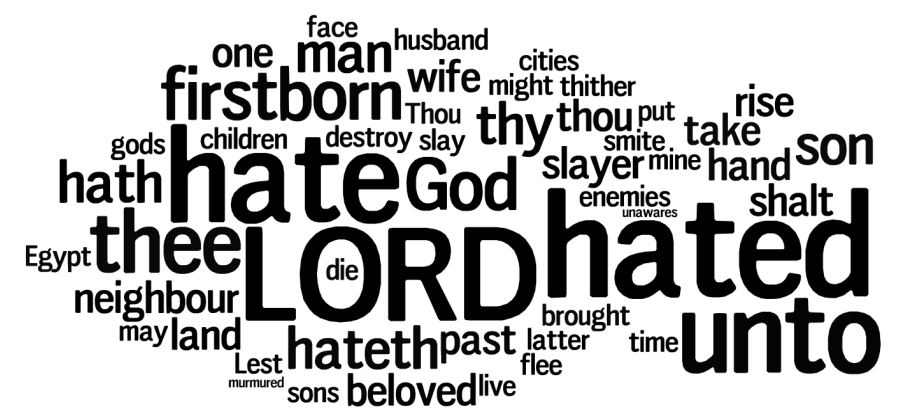

Figure 17. Most frequent words in Deuteronomy.

Theme: The Lord hates other false gods. (This book is full of what to do and what not to do in its presentation of God's law.)

Deuteronomy 5:9 Thou shalt not bow down thyself unto them, nor serve them: for I the Lord thy God am a jealous God, visiting the iniquity of the fathers upon the children unto the third and fourth generation of them that hate me. (One of the Ten Commandments of God.)

Table 3. Groups of books in the Old Testament by hate.

\begin{tabular}{cc}
\hline Cluster number & Books in one cluster \\
\hline 1 & Deuteronomy \\
2 & Ezekiel \\
3 & Genesis \\
4 & Kmos, Chronicles2, Daniel, Ecclesiastes, Esther, Exodus, Hosea, Isaiah, Jeremiah, Job, Joshua, Judges, \\
5 & Kingsiticus, Malachi, Micah, Numbers, Zechariah \\
6 & Proverbs \\
7 & Psalms \\
\end{tabular}


Deuteronomy 16:22 Neither shalt thou set thee up any image; which the Lord thy God hateth.

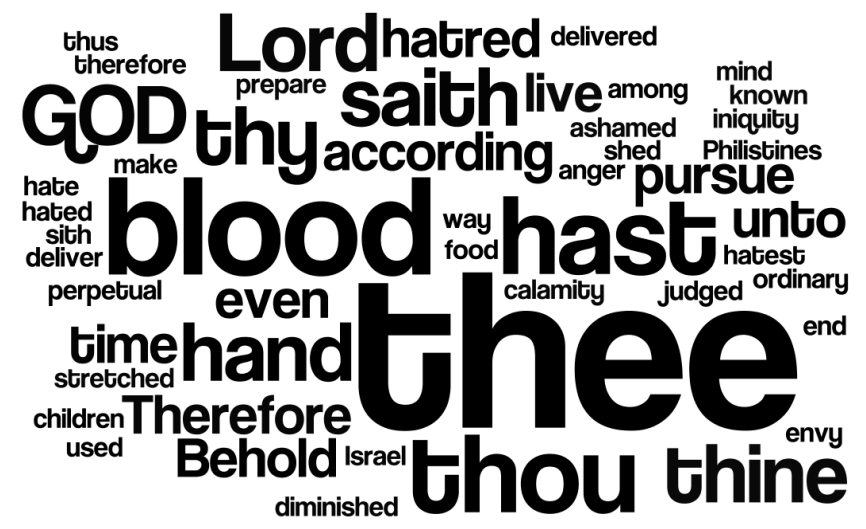

Figure 18. Most frequent words in Ezekiel.

Theme: As told by the prophet Ezekiel, God would punish the Israel people for not obeying His law by delivering them into the hands of their enemies who hated them.

Ezekiel 23:28 For thus saith the Lord God; Behold, I will deliver thee into the hand of them whom thou hatest, into the hand of them from whom thy mind is alienated. (God warned the Israelites of the coming judgment.)

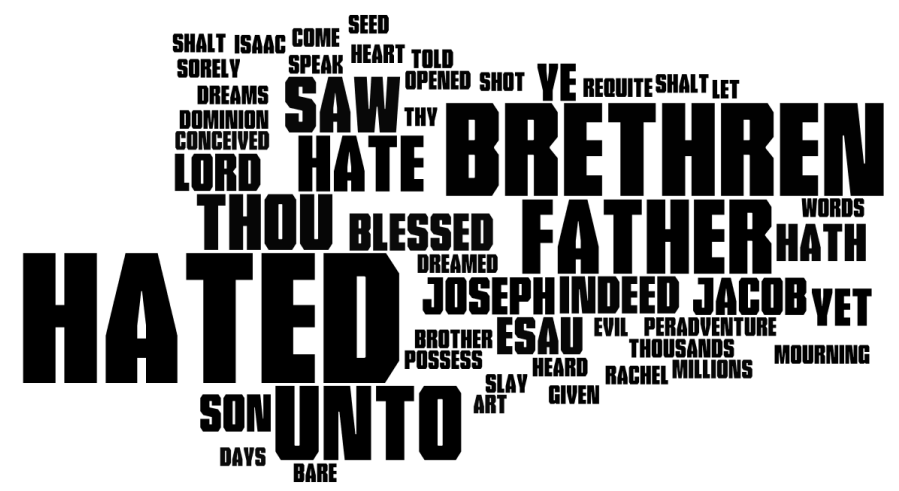

Figure 19. Most frequent words in Genesis.

Theme: Hatred among the family members: Joseph and his brethren, Esau and Jacob. Further, other members were also involved: Isaac, Rebekah, Leah, and Rachel.

Just like in most families, there were love and hatred among the family members in this book. These stories recorded in this book offer timeless spiritual lessons, which are of great value to our daily living.

Genesis 29:31 And when the Lord saw that Leah was hated, he opened her womb: but Rachel was barren.

Genesis 37:5 And Joseph dreamed a dream, and he told it his brethren: and they hated him yet the more.

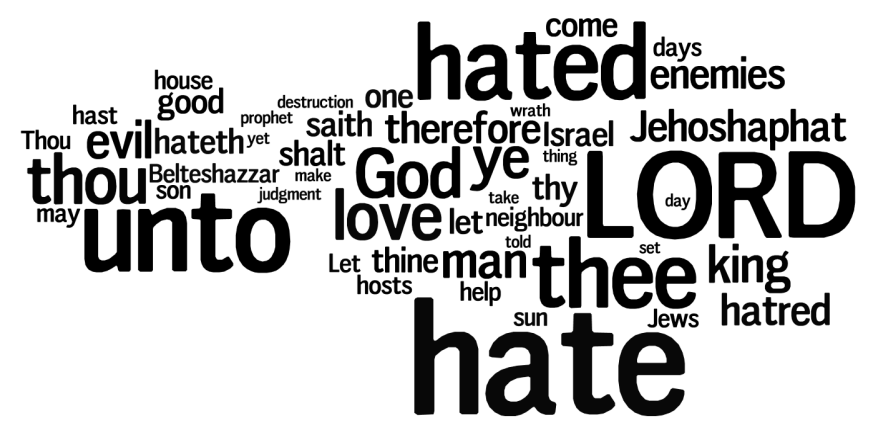

Figure 20. Most frequent words in other books of OT. 
Theme: Hate evil but love the Lord, God, neighbor, good.

Note that some verses that contain the word hate also have the word love, highlighting the two sides of the same coin.

Amos 5:15 Hate the evil, and love the good, and establish judgment in the gate: it may be that the Lord God of hosts will be gracious unto the remnant of Joseph.

Isaiah 61:8 For I the Lord love judgment, I hate robbery for burnt offering; and I will direct their work in truth, and I will make an everlasting covenant with them.

Leviticus 19:17 Thou shalt not hate thy brother in thine heart: thou shalt in any wise rebuke thy neighbour, and not suffer sin upon him.

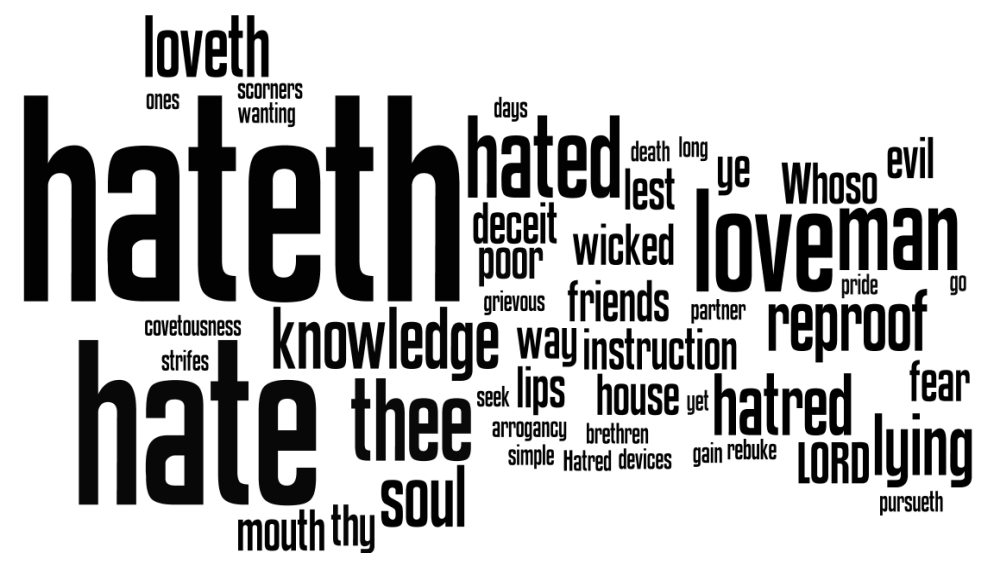

Figure 21. Most frequent words in Proverbs.

Theme: Hate evil, deceit, wicked, lying, arrogance, but love Lord, knowledge, instruction, rebuke, reproof.

In this book of wisdom, the words love and hate are simultaneously present in some verses to make a clear contrast. Biblical wisdom is strongly associated with righteousness, which is able to distinguish between right and wrong.

Proverbs 8:13 The fear of the Lord is to hate evil: pride, and arrogancy, and the evil way, and the froward mouth, do I hate.

Proverbs 10:12 Hatred stirreth up strifes: but love covereth all sins.

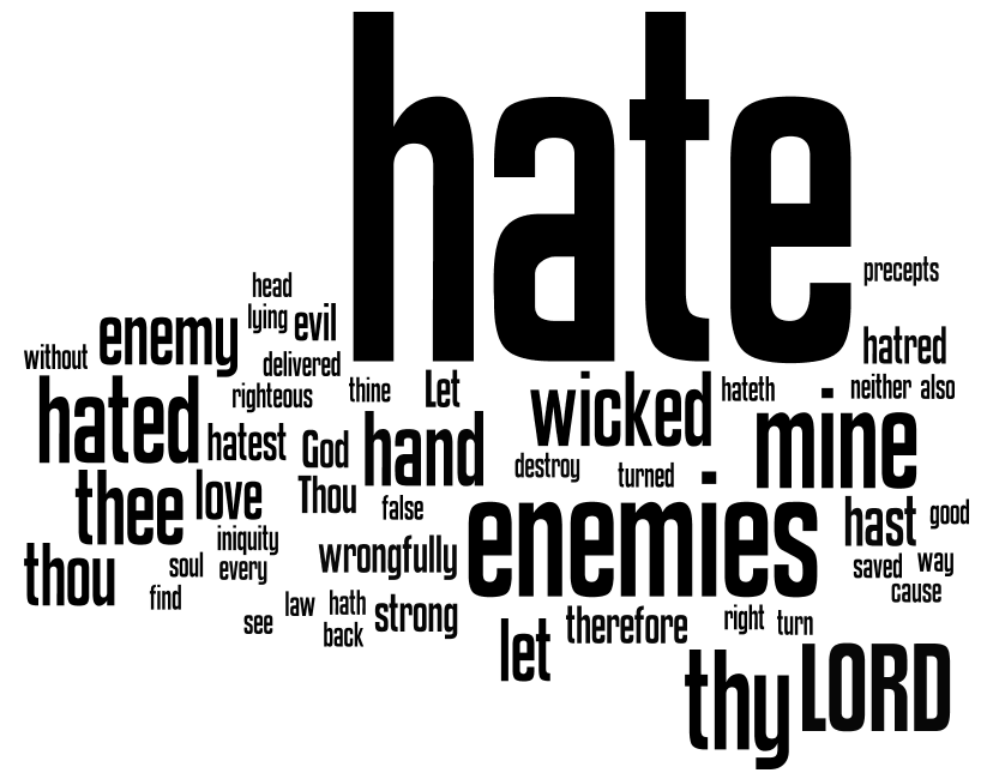

Figure 22. Most frequent words in Psalms. 
Theme: Hate and destroy enemies, wicked, evil, lying, iniquity, but love Lord, God, law, good, righteous. (The verses in this group demonstrate worshiping God in truth.)

Psalm 11:5 The Lordtrieth the righteous: but the wicked and him that loveth violence his soul hateth.

Psalm 68:1 Let God arise, let his enemies be scattered: let them also that hate him flee before him.

Psalm 119:163 I hate and abhor lying: but thy law do I love.

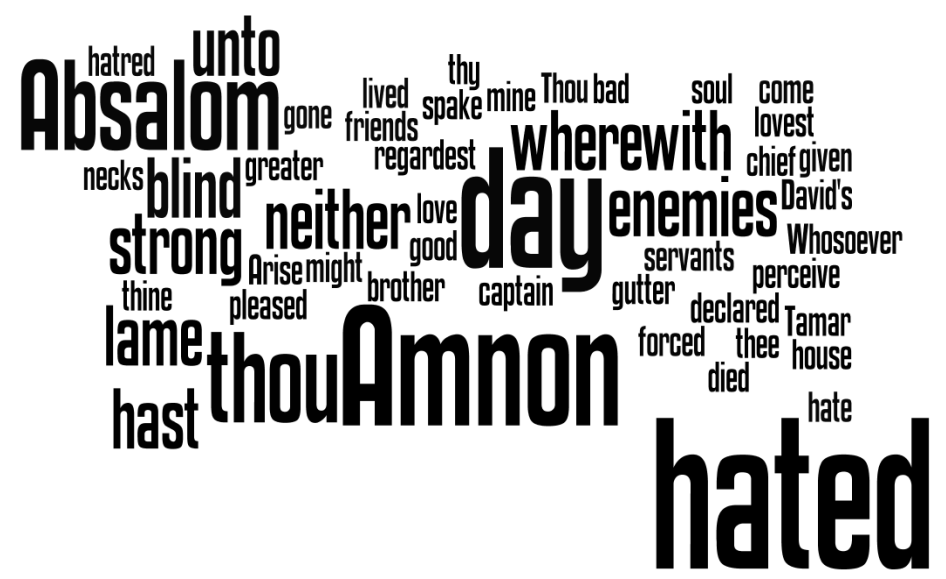

Figure 23. Most frequent words in 2 Samuel.

Theme: The verses containing the word hate in this book feature the story of Absalom, Amnon, and Tamar.

2 Samuel 13:22 And Absalom spake unto his brother Amnon neither good nor bad: for Absalom hated Amnon, because he had forced his sister Tamar.

\subsubsection{Clustering Books of the New Testament by Hate}

John is known as the Apostle of love. In order to enhance his teaching of what to love, he had to demonstrate what to hate as well. Our analysis implied that the verses that contain the word hate in John and 1 John were quite different from those in the other books (Table 4 and Figures 24-26). There were three groups found from the NT books that contain the word hate. Noticeably First Corinthians formed a single group of love (Table 2) but does not have any hate words.

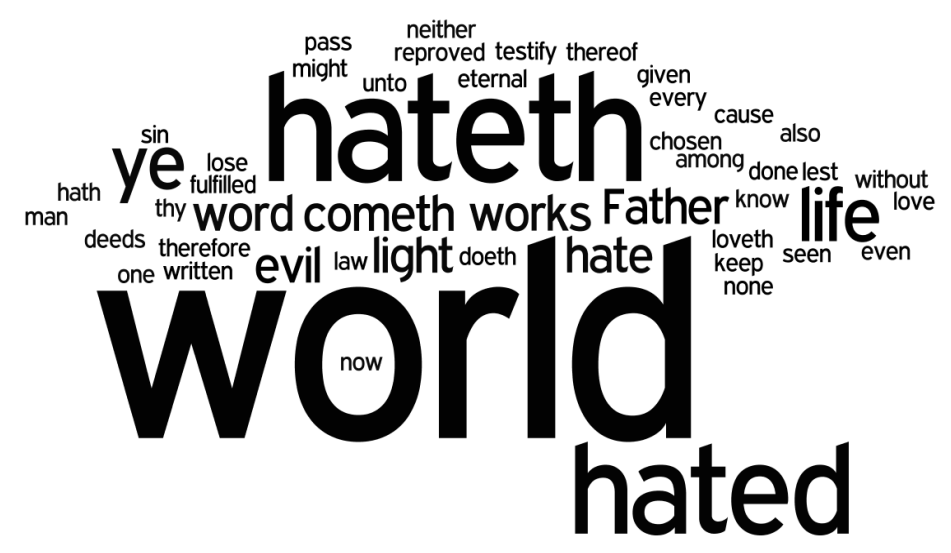

Figure 24. Most frequent words in John.

Theme: The world hates word, father, light, life, law, but loves evil, sin.

John 17:14 I have given them thy word; and the world hath hated them, because they are not of the world, even as I am not of the world.

John 3:20 For every one that doeth evil hateth the light, neither cometh to the light, lest his deeds should be reproved. 
Table 4. Groups of books in the New Testament by hate.

\begin{tabular}{cc}
\hline Cluster number & Books in one cluster \\
\hline 1 & John \\
2 & John1 \\
3 & Ephesians, Galatians, Hebrews, Luke, Mark, Matthew, Revelation, Romans \\
\hline
\end{tabular}

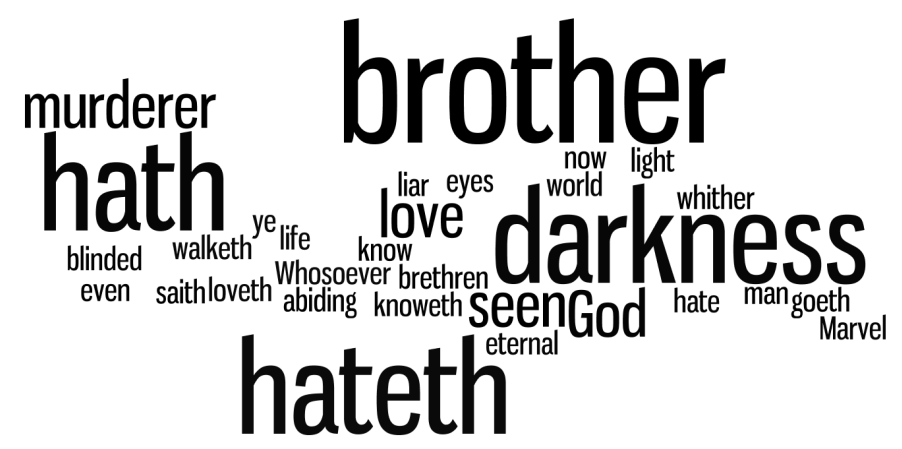

Figure 25. Most frequent words in 1 John.

Theme: Hate brother $=$ murderer $=$ in darkness.

John and 1 John are well known for their instruction on love, but here we showed that they also contain some unique verses relating what not to do in order to teach what to love. The Gospel of John emphasizes what the world would do in terms of hate, while 1 John stresses not to hate our brothers.

1 John 2:11 But he that hateth his brother is in darkness, and walketh in darkness, and knoweth not whither he goeth, because that darkness hath blinded his eyes.

1 John 3:15 Whosoeverhateth his brother is a murderer: and ye know that no murderer hath eternal life abiding in him.

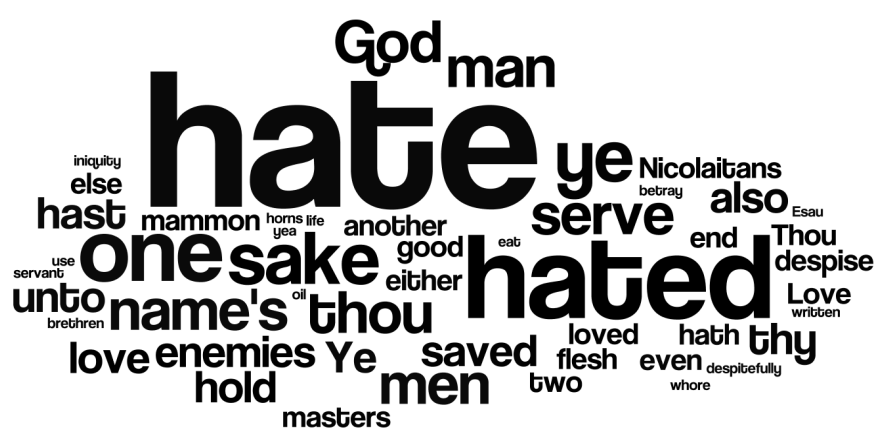

Figure 26. Most frequent words in other books of NT.

Theme: Hate and despise iniquity and mammon, but love and serve God, one another, enemies.

Several verses in the OT contain words like destroy or kill enemies, however the teaching of the NT is to love our enemies, i.e., to love those who hate us.

Luke 6:27 But I say unto you which hear, Love your enemies, do good to them which hate you.

Mark 13:13 And ye shall be hated of all men for my name's sake: but he that shall endure unto the end, the same shall be saved.

Matthew 6:24 No man can serve two masters: for either he will hate the one, and love the other; or else he will hold to the one, and despise the other. Ye cannot serve God and mammon.

\subsection{What to Love and What to Hate Concurrently}

The Bible instructs us to love God and hate sin (anything against God). To emphasize what to love, many verses 
tell what to hate along with what to love in the same verse as a contrast. Here we collected these verses in the OT and NT respectively and illustrated the word cloud of the top words (Figure 27, Figure 28) and the theme of each.

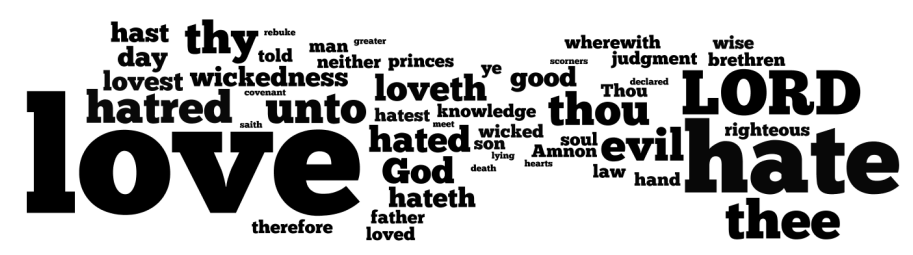

Figure 27. Most frequent words in Old Testament.

Theme: Love the Lord thy God, law, knowledge, righteous, wise, father, brethren, good, but hate evil and wickedness.

Psalm 97:10 Ye that love the Lord, hate evil: he preserveth the souls of his saints; he delivereth them out of the hand of the wicked.

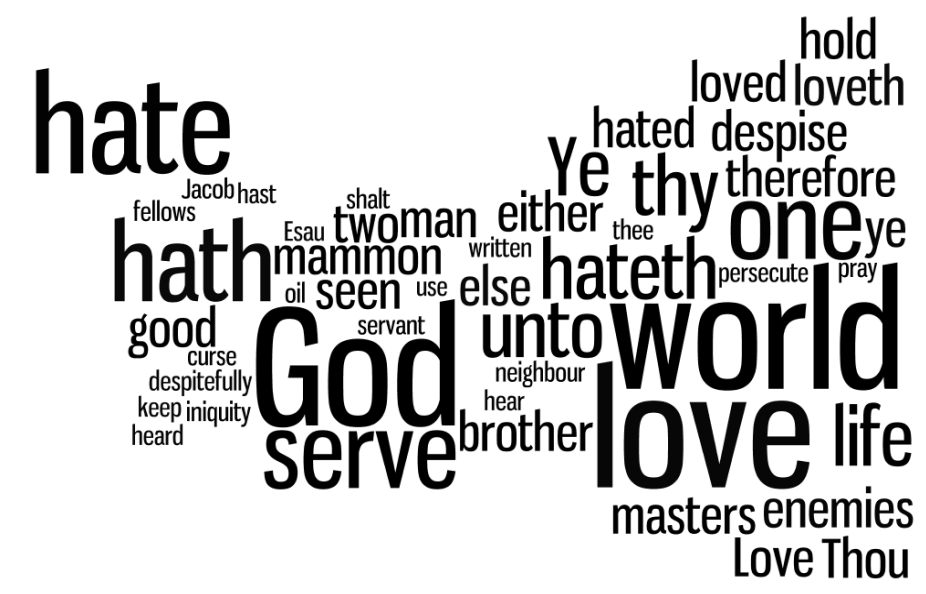

Figure 28. Most frequent words in New Testament.

Theme: Love God, one another, brother, neighbor, enemies, and hate and despise evil and mammon. (The world loves mammon and evil, but hates God.)

The major difference between the love themes in the OT and NT is that love or obey the law of God is imperative in the OT while love your enemies is prominent in the teachings of the NT, since love is described in the NT as the perfect fulfillment of the law. The OT teaches thou shall not kill whereas the NT says thou shalt not hate thy brother in thy heart, i.e., hatred is as serious as murder. Thus in a sense the law of love introduced in the NT requires more than the law of Moses does in the OT as what we have in our heart determines what life we can live.

Hebrews 1:9 Thou hast loved righteousness, and hated iniquity; therefore God, even thy God, hath anointed thee with the oil of gladness above thy fellows.

1 John 4:20 If a man say, I love God, and hateth his brother, he is a liar: for he that loveth not his brother whom he hath seen, how can he love God whom he hath not seen?

Matthew 5:44 But I say unto you, Love your enemies, bless them that curse you, do good to them that hate you, and pray for them which despitefully use you, and persecute you.

\section{Discussion}

The Bible presents the great commandment in both the OT and NT: Love the Lord your God and love your neighbors as yourself (Deut. 6:5, Lev. 19:18, Matthews 22:37 \& 39, Mark 12:30 - 21, and Luke 10:27). Remember that the order of the word love appeared in this commandment is critical. Only when people love God first, then the love for man comes naturally as an appropriate response to His love and grace. On the other hand, 
God's love is so great that He hates sins since He is holy and naturally His love is holy. All the commandments of God given in the Bible are not for His benefits but for ours. Following God, we ought to hate sin but to love sinners. Loving God means to know Him and keep all His commandments. In the books of Kings, the good kings who followed God's commandants ruled 33 years on average, however the bad kings only 11 years, which undoubtedly conveys that God is the maker of history. Therefore, a better understanding of the biblical teaching about love is important for life.

Many problems with love in this world are that we are seeking love from man first, without realizing that God is the source of love since God is love (1 John 4:8). Therefore, we must seek Him first. The Bible offers the golden rule of life: treat people the same way you want them to treat you (Matthews 7:12), which encourages us to love so we can be loved. Our daily life witnesses how this law of love works in the real world. To love God and our neighbors is the target God sets for us, and any miss of this target is sin, including not only our actions but also our thoughts and attitudes as sin starts in the heart.

There are many Bible verses pertaining to love. In First Corinthians 13 Paul explains in great detail what love does and describes the excellent way of love. Love is giving, not getting. Love treats the interest of others as primary focus and self-interest as secondary. Love one another as God has loved us first, i.e., God's love for us produces love in us. The salvation of man is available by the love of God (John 3:16). Love can involve emotions; however it is more a commitment of the will than feelings. Our emotions may vary under different circumstances but biblical love endures and is unchanging.

Though the commandments of loving God and loving neighbors are taught in both the OT and NT, but in the NT Jesus commanded to love your enemies and do not repay evil with evil. Compared to the OT, this is a distinct character of the love presented by Jesus.

The current study focused on the Bible verses that contain the word love; nevertheless there are books in the Bible that do not use this word at all. The book of Jonah, though having no plain love words, shows the great love of God Who persistently sent the prophet Jonah to preach a message of repentance to the people in the Assyrian city of Nineveh, so they could be saved from destruction. Similarly, there is no explicit mention of the word love in the book of Ruth, but the love and care between Naomi and Ruth, Ruth and Boaz were clearly evident in their acts to obey God's law and their seeking the benefits of others. Their story demonstrates that God's law is designed to love, which fulfills the law completely and perfectly. During the dark age of judges, there was this beautiful story of love between Ruth and Boaz. Years later David, a grandson of Ruth, changed the age of everyone following his own desire during the period of judges to an age of worshiping God. Although there were many events and people in history that could be recorded from a human point of view, but the Bible only recorded those that were important to God.

\section{Conclusion}

In summary, this study provided a complete catalogue of love themes presented in the Bible. Throughout the whole Bible, it highlights the primary commandment to love God and our neighbors because God is love, and to hate sin because God is holy. The Bible not only teaches what to do but also what not to do. There is a smooth focus shift from the Law of Moses in the OT to guide our actions to the law of love in the NT to guide our heart. God's commands were given out of His love for us, so they are law of life, whose purpose is to lead us to live our life to its fullness. The practice of love can truly reflect the fact that we are made in the image of God. Our desire is to ask God to fill us full of His love so it overflows naturally into the lives of others, i.e., let the light of God's love shine in us and through us.

\section{Acknowledgements}

We thank Houghton College for its financial support.

\section{References}

Blei, D., Ng, A., \& Jordan, M. (2003). Latent Dirichlet Allocation. Journal of Machine Learning Research, 3, 993-1022.

Chapman, G. D. (2009). The 5 Love Languages: The Secret to Love That Lasts. Chicago IL: Northfield Publishing.

Cowburn, J. S. J. (2003). Love. Milwaukee: Marquette University Press.

Frey, B. J., \& Dueck, D. (2007). Clustering by Passing Messages between Data Points. Science, 315, 972-976. 
http://dx.doi.org/10.1126/science.1136800

Griffiths, T. L., Steyvers, M., \& Tenenbaum, J. B. T. (2007). Topics in Semantic Representation. Psychological Review, 114, 211-244. http://dx.doi.org/10.1037/0033-295X.114.2.211

Griffiths, T., \& Steyvers, M. (2004). Finding Scientific Topics. Proceedings of the National Academy of Sciences, 101, 5228-5235. http://dx.doi.org/10.1073/pnas.0307752101

Lamb, R. E. (1997). Love Analyzed. Boulder: Westview Press.

Pons, P., \& Latapy, M. (2006). Computing Communities in Large Networks Using Random Walks. Journal of Graph Algorithms and Applications, 10, 191-218. http://dx.doi.org/10.7155/jgaa.00124

Soble, A. (1989) Eros, Agape, and Philia: Readings in the Philosophy of Love. St. Paul, Minnesota: Paragon House.

Steyvers, M., \& Griffiths, T. (2007). Probabilistic Topic Models. In T. Landauer, D. McNamara, S. Dennis, \& W. Kintsch (Eds.), Latent Semantic Analysis: A Road to Meaning. Hillsdale, NJ: Laurence Erlbaum. 
Scientific Research Publishing (SCIRP) is one of the largest Open Access journal publishers. It is currently publishing more than 200 open access, online, peer-reviewed journals covering a wide range of academic disciplines. SCIRP serves the worldwide academic communities and contributes to the progress and application of science with its publication.

Other selected journals from SCIRP are listed as below. Submit your manuscript to us via either submit@scirp.org or Online Submission Portal.
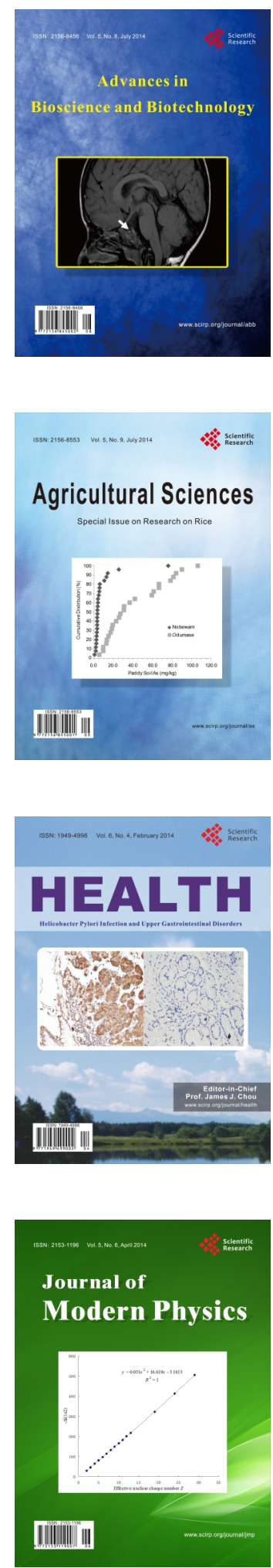
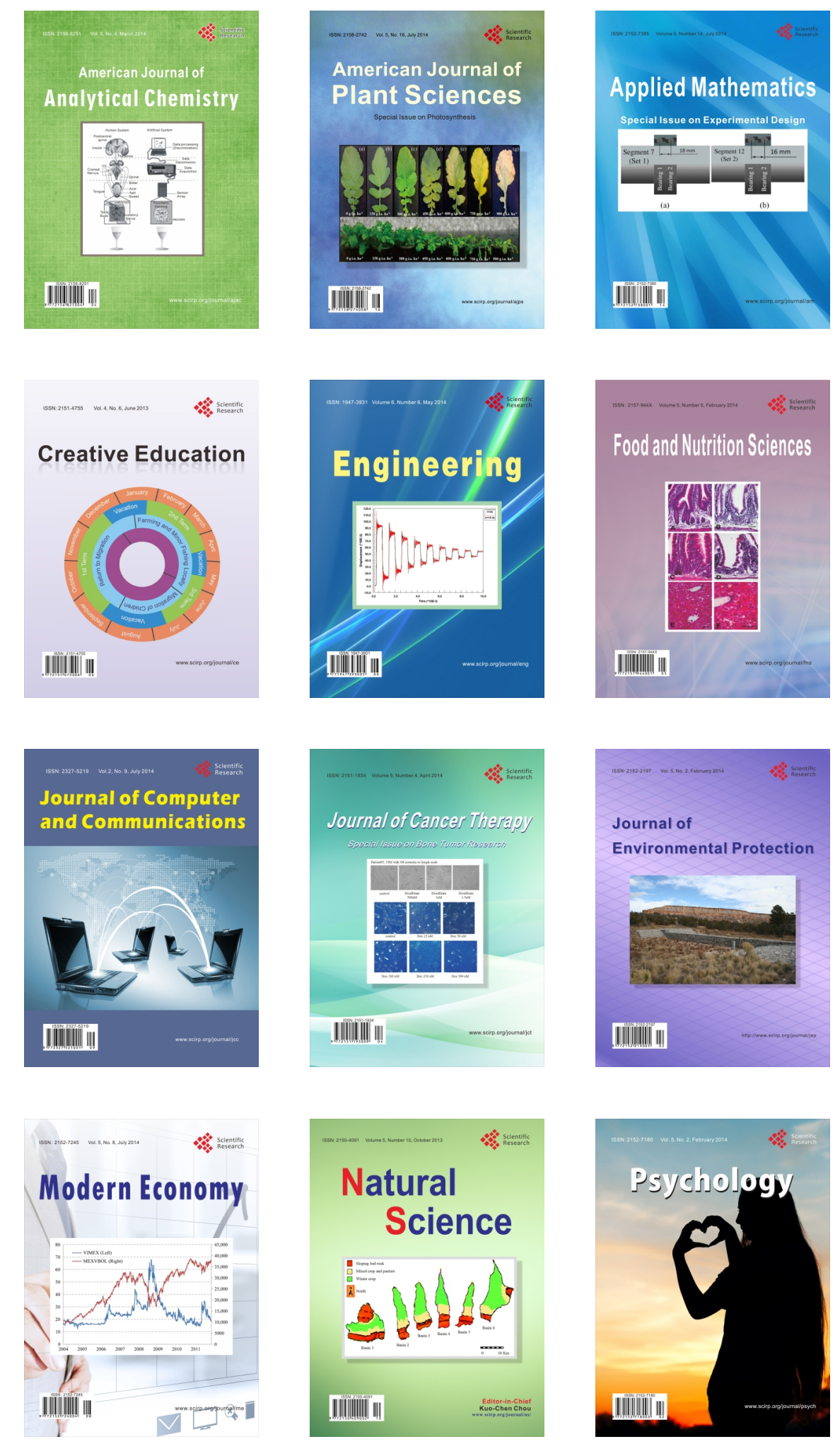